\title{
ANALISIS PENINGKATAN KUALITAS PELAYANAN DENGAN METODE QUALITY FUNCTION DEPLOYMENT (STUDI KASUS: BNI SYARIAH KCP CILANDAK)
}

\author{
Anisa Rahmah Pratiwi \\ anisarpratiwi17@gmail.com \\ Aminah \\ aminah.fauzi@gmail.com \\ Ady Arman \\ armanady@yahoo.com
}

\section{Program Studi D4 Keuangan dan Perbankan Syariah Politeknik Negeri Jakarta}

\begin{abstract}
This study aims to analyze the improvement of BNI Syariah KCP Cilandak operational services to the needs and desires of customers using the Quality Function Deployment method. This research is a qualitative descriptive study. The data used are primary data using a questionnaire instrument distributed to 134 respondents. The trial used is the validity trial and reliability trial to test the results of the questionnaire data, then the Quality Function Deployment method is used to analyze the amount of customer expectations for service, the discrepancy of customer expectations with service quality, and the main priority improvements in aspects of BNI Syariah KCP Cilandak services. The results showed the main attribute of customer priority in obtaining BNI Syariah KCP Cilandak operational services, namely the confidentiality of data of each customer is guaranteed. Then the level of discrepancy with the greatest attribute between the needs and desires of customers with the services provided by banks is to inform the difference in transactions between Islamic banks and conventional banks. Whereas the main priority as an act of BNI Syariah KCP Cilandak in meeting the needs and desires of customers is by increasing competence and responsibility towards work.
\end{abstract}

Keywords: Service Quality, Application of Quality Functions, Excellent Service, Islamic Banks.

\section{ABSTRAK}

Penelitian ini bertujuan untuk menganalisis peningkatan pelayanan operasional BNI Syariah KCP Cilandak terhadap kebutuhan dan keinginan nasabah menggunakan metode Quality Function Deployment. Jenis penelitian ini adalah penelitian deskriptif kualitatif. Data yang digunakan adalah data primer dengan menggunakan instrumen kuesioner yang disebarkan kepada 134 responden. Uji yang digunakan adalah uji validitas dan uji reabilitas untuk menguji hasil data kuesioner, selanjutnya digunakan metode Quality Function Deployment untuk menganalisis besarnya harapan nasabah terhadap pelayanan, ketidak sesuaian harapan nasabah dengan kualitas pelayanan, dan proritas utama perbaikan dalam aspek pelayanan BNI Syariah KCP Cilandak. Hasil penelitian menunjukkan atribut utama yang menjadi prioritas nasabah dalam memperoleh pelayanan operasional BNI Syariah KCP Cilandak yaitu kerahasiaan data setiap nasabah terjamin. Kemudian tingkat ketidaksesuaian atribut paling besar antara kebutuhan dan keinginan nasabah dengan pelayanan yang diberikan oleh bank yaitu menginformasikan perbedaan transaksi pada bank syariah dengan bank konvensional. Sedangkan prioritas utama sebagai tindakan BNI Syariah KCP Cilandak dalam memenuhi kebutuhan dan keinginan nasabah yaitu dengan meningkatkan sikap kompeten dan bertanggung jawab terhadap pekerjaan.

Kata Kunci: Kualitas Pelayanan, Quality Function Deployment, Pelayanan Prima, Bank Syariah.

\section{PENDAHULUAN}

\section{Latar Belakang}

Hingga November 2018, terdapat 115 bank di Indonesia, 101 bank di antaranya adalah Bank Umum dan 14 bank di antaranya adalah Bank Umum Syariah. Hal ini menjadikan persaingan perbankan di Indonesia sangat kompetitif. Setiap bank selalu berusaha untuk memberikan yang terbaik bagi nasabahnya dalam rangka menghadapi persaingan. Oleh karena itu, salah satu cara mengatasi permasalahan ini adalah dengan memberikan pelayanan prima agar terciptanya kepuasan pelanggan.
Tercapainya kepuasan pelanggan merupakan senjata ampun bagi perusahaan untuk dapat memasuki kancah persaingan, mencapai competitive advantages, dan meningatkan pangsa pasar. Pada tahun 2018 PT BNI Syariah menerima penghargaan $3^{\text {rd }}$ Best Overall Performance Sharia Bank dalam acara Infobank Banking Service Excellence Awards 2018 yang diselenggarakan oleh Majalah Infobank bersama Market Research Indonesia. Pencapaian tersebut memicu BNI Syariah untuk lebih meningkatkan pelayanannya kepada nasabah ke depannya danmenetapkan target untuk memperoleh peringkat pertama pada tahun 2019 . 


\section{Rumusan Masalah Penelitian}

Ketatnya persaingan antar bank di Indonesia memicu setiap bank untuk memberikan yang terbaik bagi nasabahnya dari berbagai aspek terutama aspek pelayanan. PT BNI Syariah perlu melakukan peningkatan pelayanan operasional sesuai dengan kebutuhan dan keinginan nasabah, sehingga dapat memberikan pelayanan terbaik terhadap nasabah, membuat nasabah loyal dan memicu nasabah melakukan transaksi kembali di PT BNI Syariah.

Kebutuhan dan keinginan nasabah dapat diukur menggunakan tools untuk menerjemahkan secara kualitatif yakni dengan Quality Function

Deployment.

\section{Tujuan Penelitian}

Berdasarkan rumusan masalah, maka tujuan penelitian ini yaitu:

1. Mengetahui dan menganalisis besarnya harapan nasabah atas kualitas layanan pada BNI Syariah KCP Cilandak.

2. Mengetahui dan menjelaskan besarnya tingkat kesesuaian kebutuhan dan keinginan nasabah atas kualitas layanan dengan pelayanan yang diberikan oleh BNI Syariah KCP Cilandak.

3. Untuk mengetahui variabel prioritas utama yang perlu diperbaiki oleh BNI Syariah KCP Cilandak.

\section{TINJAUAN PUSTAKA}

\section{Pelayanan}

Menurut Moenir (2010, p. 26) pelayanan adalah kegiatan yang dilakukan oleh seseorang atau sekelompok orang dengan landasan faktor materi melalui sistem, prosedur dan metode tertentu dalam rangka usaha memenuhi kepentingan orang lain sesuai dengan haknya. Pelayanan memiliki empat karakteristik utama menurut Tjiptono (2012, p. 28), yaitu:

1. Tidak Berwujud (Intangibility); berbeda secara signifikan dengan barang fisik.

2. Bervariasi (Heterogeneity); bersifat heterogen karena merupakan non- standardized output, artinya bentuk, kualitas dan jenisnya sangat beraneka ragam, tergantung pada siapa, kapan, dan dimana layanan tersebut dihasilkan.

3. Tidak Terpisahkan (Inseparability); jasa umumnya dijual terlebih dahulu, baru kemudian diproduksi dan dikonsumsi pada waktu dan tempat yang sama

4. Tidak Tahan Lama (Perishability); merupakan komoditas yang tidak tahan lama, tidak dapat disimpan untuk pemakaian ulang di waktu yang akan datang, dijual kembali, atau dikembalikan.

Di dalam penelitian yang dilakukan Fadla (2016, p. 38) menjelaskan bahwa sikap melayani adalah salah satu prinsip bisnis yang islami. Pepatah dalam bahasa arab mengatakan "Sayyidul qaumi khadimuhum" (pengusaha adalah pelayan bagi customernya). Karena itu, sikap murah hati, ramah, dan sikap melayani mestilah menjadi bagian dari kepribadian semua karyawan yang bekerja.

Adapun budaya kerja dalam pandangan Islam yang merupakan kunci kesuksesan Nabi Muhammad SAW. berbisnis dilandasi oleh:

1. Jujur (Shiddiq); tidak berbohong, tidak menipu, tidak mengada-ngada fakta, tidak berkhianat serta tidak pernah ingkar janji.

2. Tanggung Jawab (Amanah); dapat dipercaya, bertanggung jawab, dan kredibel.

3. Komunikatif (Tabligh); komunikatif dan argumentatif.

4. Bijaksana (Fathanah); , memahami, dan menaati secara mendalam segala hal yang menjadi tugas dan kewajiban.

5. Istiqamah; konsisten dalam iman dan nilai- nilai yang baik meskipun menghadapi berbagai godaan dan tantangan.

\section{Pelayaanan Prima}

Daryanto (2014, p. 51) berpendapat

bahwa "Pelayanan prima (excellent service) merupakan suatu pelayanan terbaik dalam memenuhi harapan dan kebutuhan pelanggan yang memenuhi standar kualitas sehingga menumbuhkan kepuasan pelayanan terhadap

pelanggan". Tujuan pelayanan prima menurut Daryanto (2014, p. 51) yaitu:

1. Untuk memberikan pelayanan yang bermutu tinggi kepada pelanggan.

2. Untuk menimbulkan keputusan dari pihak pelnggan agar segera membeli barang/jasa yang ditawarkan pada saat itu juga.

3. Untuk menumbuhkan kepercayaan pelanggan terhadap pelanggan terhadap barang/jasa yang ditawarkan.

4. Untuk menghindari terjadinya tuntutantuntutan yang tidak perlu dikemudian hari terhadap produsen.

5. Untuk menciptakan kepercayaan dan kepuasan kepada pelanggan

6. Untuk menjaga agar pelanggan merasa diperhatikan segala kebutuhannya.

Menurut Zeithaml dkk dalam Hardiyansyah (2011, p. 46), kualitas pelayanan dapat diukur dari lima dimensi yaitu:

1. Tangibles, atau bukti fisik yaitu kemampuan suatu perusahaan dalam menunjukkan eksistensinya pada pihak eksternal.

2. Reliability, atau kehandalan yaitu kemampuan perusahaan untuk memberikan pelayanan sesuai yang telah dijanjikan secara akurat, tepat waktu, dan dapat dipercaya.

3. Responsiveness, atau ketanggapan yaitu suatu kemauan untuk membantu dan memberikan pelayanan yang cepat dan tepat kepadapelanggan, dengan penyampaian informasi yang jelas.

4. Assurance, atau jaminan dan kepastian dari karyawan (contact personnel) dikaitkan dengan kemampuan mereka dalam memberikan 
keyakinan kepada pelanggan bahwa pihak penyedia jasa mampu memberikan pelayanan dengan sebaik- baiknya.

5. Empathy, yaitu memberikan perhatian yang tulus dan bersifat pribadi yang diberikan kepada pelanggan dengan berupaya memahami keinginan konsumen.

Menurut Othman dan Owen (2001) dikutip dari Fitriani (2018, p. 15), dimensi tangibles, reliability, responsiveness, assurance dan empathy telah terbukti merupakan instrumen terpopuler untuk mengukur kualitas pelayanan karena kemampuan teknisnya untuk mengukur dan mengatur kualitas pelayanan. Namun, karena bank syariah beroperasi dibawah prinsip dan budaya yang berbeda dengan industri pelayanan yang lainnya, maka perlu ditambahkan satu dimensi lagi yaitu compliance yang dikenal dengan compliance with islamic law (kepatuhan terhadap hukum Islam). Compliance, yaitu kepatuhan atau kemampuan perusahaan agar sesuai dengan hukum Islam dan prinsip-prinsip perbankan dan ekonomi Islam.

\section{Kepuasan Pelanggan}

Kepuasan pelanggan memiliki pengaruh yang cukup besar terhadap keinginan pelanggan untuk kembali membeli sebuah produk atau kembali menggunakan sebuah jasa. Dalam difinisinya, kepuasan merupakan tingkat perasaan dimana seseorang menyatakan hasil perbandingan atas kinerja produk jasa yang diterima dengan yang diharapkan (Kotler, 2014, p. 158). Menurut Zeithaml dan Bitner dalam Rangkuti (2017: 37) terdapat Zone of Tolerance sebagaia pengukur kepuasan pelanggan. Zone of Tolerance adalah daerah diantara kinerja perusahaan dan tingkat kerja yang diharapkan, yaitu daerah dimana variasi pelayanan yang masih dapat diterima oleh pelanggan. Apabila pelayanan yang diterima oleh pelanggan berada di bawah kinerja perusahaan, pelanggan akan kecewa. Sedangkan apabila terjadi kebalikannya, pelanggan akan merasa puas. Zone of Tolerance dapat mengembang dan menyusut, serta berbeda-beda untuk setiap individu, perusahaan, situasi dan aspek jasa. Model konseptual mengenai Zone of Tolerance dapat digambarkan sebagai berikut.

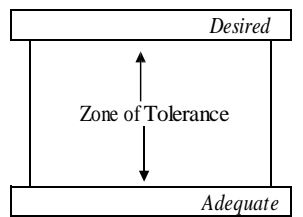

Gambar 1 Zone of Tolerance

Sumber: Freddy Rangkuti (2017, p. 37)

Menurut Kotler (2005) yang dikutip oleh Wijaya (2011, p. 66), ada empat metode dalam mengukur tingkat kepuasan pelanggan, diantaranya:

1. Sistem Keluhan dan Saran

Perusahaan yang berorientasi pada pelanggan menyediakan kesempatan yang seluas-luasnya bagi para pelanggannya untuk menyampaikan kritik, saran, dan keluhan mereka.

\section{Ghost Shopping}

Mempekerjakan beberapa orang yang berperan sebagai pelanggan atau pembeli potensial produk perusahaan dan pesaing berdasarkan pengalaman mereka dalam pembelian produk-produk tertentu. Kemudian melaporkan hal-hal tertentu yang berkaitan dengan kekuatan dan kelemahan produk, mengamati dan menilai cara penanganan yang lebih baik.

3. Lost Customer Analysis

Perusahaan berusaha menghubungi para pelanggan yang telah berhenti membeli atau beralih ke perusahaan lain. Kemudian, perusahaan berusaha mengamati apa yang menyebabkan pelanggang bisa berpindah ke produk atau jasa lain.

4. Survey Keputusan Pelanggan

Suatu cara yang dilakukan oleh perusahaan untuk memperoleh tanggapan dan umpan balik secara langsung dari pelanggan dan sekaligus juga memberikan signal positif bahwa perusahaan menaruh perhatian terhadap para pelanggannnya.

\section{METODE PENELITIAN}

Jenis penelitian yang digunakan dalam penelitian ini adalah penelitian deskriptif dengan pendekatan kuantitatif. Peneliti memilih jenis penelitian deskriptif kuantitatif karena penelitian ini mengeksplor fenomena bagaimana peningkatan kualitas pelayanan pada Bank BNI Syariah KCP Cilandak dengan menggunakan instrumen penelitian Quality Function Deployment. Metode pengambilan sampel yang digunakan dalam penelitian ini adalah accidental sampling. Besarnya jumlah sampel dalam penelitian ini dirumuskan dengan menggunakan rumus Slovin dan diperoleh hasil perhitungan jumlah sampel sebesar 134 responden. Metode pengumpulan data yang digunakan adalah kuesioner, wawancara, FGD dan observasi. Data yang telah diperoleh selanjutnya dianalisis menggunakan uji validitas, uji reliabilitas dan metode Quality Function Deployment.

\section{PEMBAHASAN}

\section{Kuesioner Penelitian}

Untuk dapat melakukan pengukuran kebutuhan dan harapan nasabah terhadap kualitas pelayanan BNI Syariah KCP Cilandak, diperoleh hasil voice of customer yang diformulasikan ke dalam bentuk kuesioner penelitian utama.

\begin{tabular}{|l|l|}
\hline \multicolumn{2}{|c|}{ Tabel 1 Voice of Customer } \\
\hline No. & Voice of Customer \\
\hline 1 & $\begin{array}{l}\text { Pegawai selalu bersikap ramah dan sopan } \\
\text { kepada nasabah }\end{array}$ \\
\hline
\end{tabular}




\begin{tabular}{|c|c|}
\hline 2 & $\begin{array}{l}\text { Memberikan arahan kepada nasabah } \\
\text { sebelum melakukan transaksi sesuai } \\
\text { dengan kebutuhan nasabah }\end{array}$ \\
\hline 3 & $\begin{array}{l}\text { Pelayanan dapat menumbuhkan rasa } \\
\text { kepercayaan kepada BNI Syariah }\end{array}$ \\
\hline 4 & $\begin{array}{l}\text { Pegawai memiliki pengetahuan mengenai } \\
\text { berbagai macam produk yang } \\
\text { ditawarkannya }\end{array}$ \\
\hline 5 & $\begin{array}{l}\text { Tidak terjadi kesalahan dalam menjalani } \\
\text { transaksi }\end{array}$ \\
\hline 6 & $\begin{array}{l}\text { Pelayanan sesuai dengan jangka waktu } \\
\text { yang dijanjikan }\end{array}$ \\
\hline 7 & $\begin{array}{l}\text { Pelayanan tepat dan akurat sesuai dengan } \\
\text { yang telah dijanjikan }\end{array}$ \\
\hline 8 & Jam buka jelas dan tepat \\
\hline 9 & $\begin{array}{l}\text { Kondisi banking hall rapi, bersih dan } \\
\text { nyaman saat jam operasional }\end{array}$ \\
\hline 10 & $\begin{array}{l}\text { Jumlah Counter Customer Service/Teller } \\
\text { memadai }\end{array}$ \\
\hline 11 & Berpenampilan rapi dan berseragam \\
\hline 12 & Kerahasiaan data setiap nasabah terjamin \\
\hline 13 & $\begin{array}{l}\text { Memberikan pelayanan sepenuh hati } \\
\text { kepada setiap nasabah }\end{array}$ \\
\hline 14 & $\begin{array}{l}\text { Dalam memberikan pelayanan, pegawai } \\
\text { tidak lupa menyebutkan nama nasabah }\end{array}$ \\
\hline 15 & Pegawai bersedia membantu nasabah \\
\hline 16 & $\begin{array}{l}\text { Pegawai tidak kerepotan } \\
\text { menanggapi permintaan nasabah }\end{array}$ \\
\hline 17 & $\begin{array}{l}\text { Pelayanan yang diberikan cepat dan } \\
\text { efisien }\end{array}$ \\
\hline 18 & Pegawai berperilaku sesuai akhlak Islam \\
\hline 19 & $\begin{array}{l}\text { Menginformasikan perbedaan transaksi } \\
\text { pada bank syariah dengan bank } \\
\text { konvensional }\end{array}$ \\
\hline 20 & $\begin{array}{l}\text { Memberikan pelayanan produk sesuai } \\
\text { dengan prinsip-prinsip Islam }\end{array}$ \\
\hline
\end{tabular}

Sumber: Wawancara, data diolah (2019)

Pada Tabel 1 dapat dilihat hasil voice of customer dari hasil penelitian pendahuluan terdapat 20 atribut pernyataan, selanjutnya akan dijadikan pernyataan dalam kuesioner untuk menilai seberapa besar tingkat kepuasan dan tingkat kepentingan atribut tersebut dalam pelayanan operasional. Hasil dari pada kuesioner tersebut selanjutnya akan dianalisis menggunakan metode Quality Function Deployment.

\section{Uji Validitas}

Uji validitas bertujuan untuk mengetahui apakah pertanyaan dalam kuesioner mampu mengukur variabel dalam kuesioner tersebut. Dari penyebaran kuesioner kepada 134 responden dengan interval kepercayaan $95 \%$ maka diperoleh batas $r$ tabel sebesar 0,1416 . Hasil yang diperoleh dari 20 pernyataan mengenai tingkat kepuasan nasabah terhadap pelayanan BNI Syariah KCP Cilandak seluruhnya dinyatakan valid. Kemudian hasil yang diperoleh mengenai tingkat kepentingan terhadap pelayanan BNI Syariah KCP Cilandak pun seluruhnya dinyatakan valid.

\section{Uji Reliabilitas}

Pengujian reliabilitas ini menggunakan koefisien Cornbach Alpha dan memperoleh hasil sebagai berikut.

Tabel 2 Uji Reliabilitas
\begin{tabular}{|c|c|}
\hline Cronbach's Alpha & N of Items \\
\hline 0.862 & 20 \\
\hline
\end{tabular}

Sumber: Data diolah (2019)

Karena nilai Cronbach's Alpha 0,862 > 0,60 maka sebagaimana dasar pengambilan keputusan dalam uji reliabilitas di atas, dapat disimpulkan bahwa semua item pernyataan pada kuesioner adalah reliabel atau konsisten.

\section{Quality Function Deployment Pembuatan Matriks House of Quality Identifikasi Suara Pelanggan}

Atribut-atribut kualitas pelayanan yang telah diperoleh kemudian dijadikan masukkan utama dalam analisis QFD sebagai suara pelanggan dalam perencanaan kualitas pelayanan laboratorium matematika. Atribut-atribut yang menjadi suara pelanggan tersebut dapat dilihat pada Tabel 1.

\section{Pembentukan Planning Matrix}

Matriks perencanaan (Planning matrix) merupakan analisis terhadap voice of customer yang meliputi: tingkat kepentingan pelayanan, performansi pelayanan, goal dan improvement ratio, sales point, raw weight dan normalized raw weight.

\section{Tingkat Kepentingan (Importance to Customer)}

Jika dilihat dari hasil tingkat kepentingan, secara umum nasabah menilai semua atribut pelayanan penting. Tiga atribut utama yang dianggap penting oleh nasabah adalah menjamin kerahasiaan data setiap nasabah, memberikan produk yang sesuai dengan prinsip islam dan pengetahuan pegawai mengenai berbagai macam produk yang ditawarkan. Apabila diperhatikan ketiga atribut tersebut memang sangat berkaitan dan berpengaruh besar dalam kualitas pelayanan operasional bank syariah. Sedangkan untuk salah satu atribut yang dianggap tidak terlalu penting oleh nasabah adalah pegawai bank tidak lupa menyebutkan nama nasabah dalam memberikan pelayanan. 


\section{Tingkat Kinerja (Customer Satisfaction Performance)}

Jika dilihat dari tingkat kinerja, secara umum nasabah menilai puas terhadap pelayanan yang diberikan dengan tingkat kinerja rata-rata bernilai 4 . Atribut yang dianggap kinerjanya paling kecil oleh nasabah sehingga memberikan kepuasan yang kecil yaitu Jumlah Counter Customer Service/Teller pada BNI Syariah KCP Cilandak memadai”. Hal ini menandakan nasabah kurang puas dengan jumlah counter yang tersedia saat ini dan harus dilakukan perbaikan untuk ke depannya. Sedangkan untuk salah satu atribut yang dianggap kinerjanya sangat baik oleh nasabah Pegawai BNI Syariah KCP Cilandak berpenampilan rapi, dan berseragam". Hal ini menandakan bahwa BNI Syariah KCP Cilandak unggul dalam hal factor intangibles, dan telah memenuhi ekspektasi nasabah dalam hal penampilan.

\section{Menentukan Nilai Target (Goal)}

Goal merupakan level performance yang ingin dicapai oleh bank untuk memenuhi kebutuhan dan keinginan nasabah (customer needs Untuk memperoleh data goals ini, dilakukan focus group discussion dan pemberian kuesioner kepada Operational Service Head BNI Syariah KCP Cilandak yang sedang menjabat pada bulan Juli 2019. dari 20 atribut customer requirements, terdapat 10 atribut di antaranya yang dinilai 5 atau sangat prioritas oleh BNI Syariah KCP Cilandak, salah satunya adalah "Pegawai selalu memiliki pengetahuan mengenai berbagai macam produk yang ditawarkannya". Kemudian terdapat 8 atribut yang dinilai 4 atau prioritas, salah satunya adalah "Pegawai selalu bersikap ramah dan sopan kepada nasabah". Serta terdapat 2 atribut yang dinilai kurang prioritas antara lain "Pelayanan sesuai jangka waktu dijanjikan" dan "Jumlah Counter Customer Service/Teller memadai", hal ini dikarenakan KCP Cilandak merasa keadaan saat itu tidak memungkinkan untuk menambahkan jumlah counter dan pembuatan kartu ATM pesanan terkadang terlambat untuk diberikan karena atrian pembuatan yang panjang.

\section{Menganalisis Improvement Ratio}

Apabila dibandingkan antara tingkat kepuasan dengan goal yang ingin dicapai perusahaan, diperoleh bahwa terdapat sembulan atribut pelayanan yang tingkat kepuasannya telah mencapai goal yang diharapkan. Sedangkan sebelas atribut pelayanan lainnya belum mencapai tingkat kepuasan pelanggan, sehingga atribut pelayanan tersebut masih harus terus ditingkatkan untuk memenuhi harapan dan keinginan nasabah dalam memperoleh layanan di BNI Syariah KCP Cilandak. Adapun tiga atribut utama yang dibutuhkan oleh nasabah, memiliki nilai target tinggi dan belum tercapai tingkat kepuasannya antara lain: pegawai menginformasikan perbedaan transaksi pada bank syariah dengan bank konvensional, memiliki pengetahuan mengenai berbagai macam produk yang ditawarkannya, dan kerahasiaan data setiap nasabah terjamin.

\section{Menentukan Sales Point}

Sales point merupakan Informasi kemampuan memberikan pelayanan berdasarkan seberapa baik kebutuhan nasabah terpenuhi. Nilainya adalah:

A. Nilai $1,00=$ sales point tidak memberikan pengaruh, tambahan manfaat dan tidak mengurangi mutu pelayanan

B. Nilai $1,25=$ sales point memberikan pengaruh kecil, dan diperlukan perbaikan dari segi teknik

C. Nilai $1,50=$ sales point memberikan pengaruh besar, dan diperlukan ditekankan pada pemasaran produk.

Untuk menentukan nilai sales point ini, maka dilakukan kuesioner dan FGD secara langsung kepada pihak bank.

Hasil mengenai Sales Point dapat dilihat pada Tabel 3 berikut:

Tebel 3 sales point

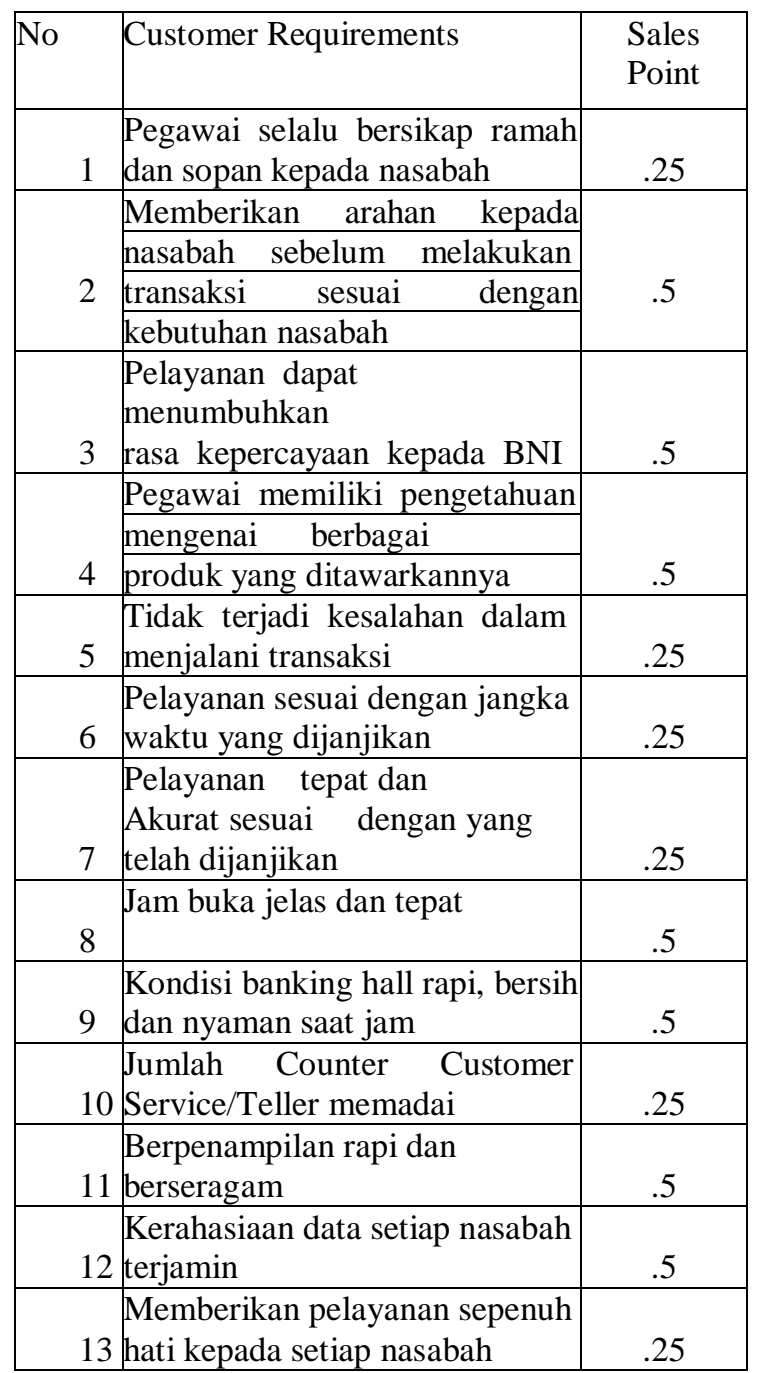




\begin{tabular}{|l|l|c|}
\hline 14 & \multicolumn{1}{|c|}{$\begin{array}{l}\text { Dalam memberikan } \\
\text { pelayanan pegawai tidak lupa } \\
\text { menyebutkan nama nasabah, }\end{array}$} & .5 \\
\hline 15 & $\begin{array}{l}\text { Pegawai bersedia membantu } \\
\text { nasabah }\end{array}$ & 5 \\
\hline & $\begin{array}{l}\text { Pegawai tidak kerepotan } \\
16 \\
\text { dalam menanggapi permintaan } \\
\text { nasabah }\end{array}$ & 25 \\
\hline 17 & $\begin{array}{l}\text { Pelayanan yang diberikan } \\
\text { cepat dan efisien }\end{array}$ & 25 \\
\hline 18 & Pegawai berperilaku sesuai & \\
\hline 9 & Menginformasikan perbedaan & .5 \\
\hline 20 & Memberikan pelayanan produk & 5 \\
\hline Sumber: Tanggapan kuesioner, data diolah \\
$(2019)$
\end{tabular}

\section{Menghitung Raw Weigth dan Normalized Raw Weight}

Penghitungan raw weight bertujuan untuk mengetahui tingkat kepentingan secara keseluruhan untuk menentukan prioritas perbaikan pelayanan operasional bank. Atribut yang memiliki nilai raw weight tinggi akan menjadi prioritas utama untuk ditingkatkan dalam memenuhi kepuasan mahasiswa. Berdasarkan nilai raw weight, dapat disimpulkan lima atribut utama yang harus diprioritaskan dan diperhatikan oleh pihak bank dalam memberikan pelayanan optiomal kepada mahasiswa, antara lain kompeten dan bertanggung jawab terhadap pekerjaan, memiliki sikap positif, empati, antusias serta responsif, dan memiliki mind set rasa peduli dan menolong sebagai ladang untuk beribadah.

\section{PENUTUP}

\section{Kesimpulan}

Berdasarkan hasil penelitian dan pembahasan yang telah dipaparkan sebelumnya, maka dapat diperoleh kesimpulan sebagai berikut:

1. Harapan nasabah atas kualitas layanan pada BNI Syariah KCP Cilandak adalah besar. Harapan nasabah paling besar atas atribut pelayanan adalah "Kerahasiaan data setiap nasabah terjamin". Menunjukkan kerahasiaan data setiap nasabah adalah hal diharapka untuk diperoleh dalam pelayanan bagi nasabah BNI Syariah KCP Cilandak.

2. Terdapat ketidaksesuaian antara kebutuhan dan keinginan nasabah atas kualitas pelayanan yang diberikan oleh BNI Syariah KCP Cilandak. Ketidaksesuaian terjadi karena besarnya nilai prioritas (goal) perusahaan lebih besar dari tingkat kepuasan pelanggan (customer satisfaction performance) terhadap pelayanan. Atribut pelayanan yang paling tidak sesuai dengan harapan nasabah yaitu "Menginformasikan perbedaan transaksi pada bank syariah dengan bank konvensional". Hal ini berarti cara pegawai BNI Syariah KCP

Cilandak dalam memberikan informasi mengenai perbedaan transaksi pada bank syariah dengan bank konvensional kurang memenuhi harapan nasabah.

3. Terdapat tiga variabel yang menjadi prioritas utama dalam perbaikan pelayanan untuk BNI Syariah KCP Cilandak, yaitu kompeten dan bertanggung jawab terhadap pekerjaan, memiliki sikap positif, empati, antusias serta responsif, dan memiliki mind set rasa peduli dan menolong sebagai ladang untuk beribadah.

\section{Saran}

Berdasarkan kesimpulan yang telah dijabarkan, maka saran yang dapat diberikan terkait pengembangan pelayanan operasional BNI Syariah KCP Cilandak, antara lain:

1. Untuk memperbaiki salah satu atribut pelayanan yang tidak sesuai dengan harapan nasabah yaitu "Menginformasikan perbedaan transaksi pada bank syariah dengan bank konvensional", dapat dilakukan perubahan cara penyampaian informasi mengenai perbedaan transaksi pada bank syariah dengan bank konvensional seperti menampilkan tabel perbedaan dan perbandingan bank syariah dan bank konvensional paling mendasar dalam layar komputer ketika menjelaskan kepada nasabah.

2. Tiga prioritas utama yang dapat dilakukan pihak BNI Syariah KCP Cilandak dalam memperbaiki pelayanan adalah dengan meningkatkan sikap kompeten dan bertanggung jawab terhadap pekerjaan, memiliki sikap positif, empati, antusias serta responsif dan memiliki mind set rasa peduli dan menolong sebagai lahan untuk beribadah. Ketiga atribut tersebut akan berpengaruh secara positif kepada kebutuhan dan keinginan nasabah sebagaimana telah dijelaskan dalam analisis ini.

3. BNI Syariah KCP Cilandak sebaiknya untuk melakukan survey secara berkala dan rutin terhadap pelayanan operasionalnya dengan tujuan untuk mengetahui penilaian nasabah terhadap pelayanan yang telah diberikan, sehingga penilaian nasabah tersebut dapat dijadikan sebagai bahan evaluasi untuk terus meningkatkan kualitas pelayanan dan pengembangan pelayanan operasional terhadap nasabah di masa yang akan datang.

\section{DAFTAR PUSTAKA}

Barata, A. A. (2014). Dasar-Dasar PelayananmPrima. Jakarta: PT Elex Media Komputindo.

Fadla, A. (2016). Pelayanan pada PT Pos Indonesia Pekanbaru Menurut Perspektif 
Islam. Pekanbaru: Universitas Islam Negeri Sultan Syarif Kasim Riau.

Daryanto. (2014). Konsumen dan Pelayanan Prima. Yogyakarta: Gava Media. Hardiyansyah. (2011). Kualitas Pelayanan Publik. Yogyakarta: Gava Media. Kotler, Philip, \& Lane Keller. (2012). Manajemen Pemasaran. Jakarta: Erlangga.

Moenir, H. (2010). Manajemen Pelayanan Umum di Indonesia. Jakarta: Bumi Aksara.

Mukarom, Z. (2015). Manajemen Pelayanan Publik. Jakarta: Pustaka Setia.

Otoritas Jasa Keuangan. (2018). Statistik Perbankan Indonesia Volume 16 No. 12. Jakarta Pusat.

Putra, D. (2018, Juni 5). Enam Bank Raih Special Awards Service Excellence 2018. Diambil kembali dari Info Bank News: http://infobanknews.com/enam-bank-raihspecial-awards-service excellence-2018 Saputra, F. I. (2013). Kualitas Layanan, Citra dan Pengaruhnya terhadap Loyalitas melalui Kepuasan Pelanggan. Jurnal Aplikasi Manajemen Volume II Nomor 3, 455.

Rahmayanty, N. (2013). Manajemen Pelayanan Prima: Mencegah Pembelotan dan Membangun Customer Loyality. Yogyakarta: Graha Ilmu.

Rangkuti, F. (2017). Measuring Customer Satisfaction. Jakarta: Gramedia.

Satori, D., \& Komariah, A. (2011). Metodologi Penelitian Kualitatif. Bandung: Alfabeta.

Siyoto, S. (2015). Dasar Metodologi Penelitian. Jakarta: Sagung Seto.

Sugiyono. (2015). Metode Penelitian Evaluasi (Pendekatan Kuantitatif, Kualitatif, dan Kombinasi). Bandung: Alfabeta.

Tjiptoo, F. (2012). Pemasaran Strategik. Yogyakarta: ANDI.

Widodo, S. (2010). Pengaruh Dimensi Kualitas Pelayanan Jasa Terhadap Kepuasan Nasabah. Jurnal Ekonomi dan Kewirausahaan Vol. 10, No. 2, 165 